\title{
Poultry welfare in developed and developing countries
}

\author{
Talha ELsadig Abbas \\ Department of Animal Production, University of ALneelain, Khartoum, Sudan
}

Email address:

talhabbs@yahoo.com

To cite this article:

Talha Elsadig Abbas. Poultry Welfare in Developed and Developing Countries. Animal and Veterinary Sciences. Vol. 2, No. 1, 2014, pp. 1-4. doi: 10.11648/j.avs.20140201.11

\begin{abstract}
Poultry welfare acquired a lot of attention in the last years especially in Europe. That appears in the activities of Animal Welfare organisations in addition to the governments of European Union which include researches and performing legislations and standards for keeping poultry. In addition, emerge of kind of consumers preferring organic foods, which are the products of poultry that mostly kept in free range system, encourage develop of poultry welfare concern. On the other hand, in the developing countries particularly in Africa the concern of animal welfare appeared recently as a proposal by the OIE (World Organisation for Animal Health) Sub-Regional Representation for Southern Africa after the $2^{\text {nd }}$ Global Conference on Animal Welfare held in Cairo in (2008) and the Workshop for OIE National Animal Welfare Focal Points for Africa held in Addis Ababa in (2010). In Africa as many other developing countries free range keeping of local chickens is the major system of production till few years ago. Then producers went forward modern production and introduced technology into poultry farming and they became aware about poultry health and growth performance. Therefore researches are concentrating on improvement of production by manipulating problems related to import of new breeds to the tropics. Hence, to establish and progress animal welfare concern in developing countries more effort by members of this Working Group will be required.
\end{abstract}

Keywords: Free Range System, Cages, Layers, Organic Foods, Welfare

\section{Introduction}

In Europe animal welfare awareness attending since (1911) whereas the UK Protection of Animals Act was present at that time [1]. This concern develops with time until gained its position nowadays in the world especially Europe. The enhancement of poultry welfare concern based mainly on scientific development in addition to governments and Organizations activities. Scientific researches considering animal welfare in developing countries are in the early stages. Furthermore, the responsibility of performing strategy to encourage OIE (World Organisation for Animal Health) animal welfare standards in Africa was held recently (after 2010) by OIE Sub-Regional Representation for Southern Africa [2].

This paper will try to exhibit housing systems and animal welfare concern in developed and developing countries, and to discuss difficulties facing progress of poultry welfare awareness in developing countries.

\section{Welfare}

Definition of poultry welfare was discussed by scientists; there is a big debate about the definition of poultry welfare. In reference [3] poultry welfare concept bases on the feeling of the animal rather than its response to the environment. In reference [4] animal welfare comprises chances for natural behavior, control of injuries and pain observation in addition to well health and physiology. Furthermore, reference [5] showed that, animal welfare concept includes comfort behavior and health appearance as a response to the surrounding environments. In general, animal welfare known as chances to perform natural behavior, free of disease, pain and distress and producing well. That means keeping of poultry in an optimal conditions where there are no signs of stress or illness according to the environment. The Farm Animal Welfare Committee $\left(\right.$ FAWC $^{1}$ ) established

\footnotetext{
${ }^{1}$ FAWC is an expert committee of the Department for Environment, Food and Rural Affairs in England; the Scottish Government's Rural Affairs and Environment Department and the Welsh Government's Departments for Environment and Sustainable Development and Business. It was established in 2011 after a review of public bodies.
} 
five freedoms to achieve good welfare. 1- Freedom from hunger and thirst, by providing accessible fresh water and diet. 2- Freedom from discomfort, by supplying suitable environment. 3- Freedom from pain, injury and disease by prevention or prompt diagnosis and treatment. 4- Freedom to express normal behavior by offering plenty space and convenient facilities. 5- Freedom from fear and distress, by providing proper conditions and treatment to prevent mental suffering [6].

\section{Housing Systems in Developed Countries}

In Europe, particularly Netherlands before 50 years poultry were maintained in low-density deep-litter systems and with the progress of poultry science housing systems were altered and developed. For laying hens, keeping system changed to the high-density battery-cage system with controlled environment and number of birds per $\mathrm{m}^{2}$ was increased. Broilers were kept in a high-density deep-litter system with controlled environment, and number of birds per $\mathrm{m}^{2}$ was also increased [7]. Then, battery-cage system became the dominant system because it is the most economic when compared to the other systems $[8,9]$. Reference [10] assured lower cost of battery-cage system in comparing with other systems. Authors noticed that as experienced by developing countries production cost of keeping laying hens in non-cage system and in organic production resembles about $8-59 \%$ and over $200 \%$ respectively, more than keeping in battery-cage system. However, in EU directive 1999/74/EC motivated to modify conventional battery-cage system and to produce new alternative systems [11]. This because battery-cage system doesn't allow sufficient space for exercise, exploration and social behavior hence it doesn't provide welfare environment as considered by FAWC.

\section{Poultry Welfare in Developed Countries}

Presence of UK Protection of Animals Act at (1911) indicates that animal welfare concern did not start recently [1]. Then, appearance of Ruth Harrison's book “Animal Machines" [12] play a role in progress of this concern. After that, according to different government activities and some publications Farm Animal Welfare Council originated in 1979. This organization suggested UK Codes of Recommendations for the farm animal's welfare which includes five freedoms mentioned above [13]. Later on this suggestion became an instruction by UK ministers [1]. In addition, existence of WPSA Working Group 9 (WG9) in 1972 embolden scientific researches and in consequence of these researches poultry welfare regarding housing systems take place and progress in Europe [1].

\section{Housing Systems in Developing Countries}

In Africa there are three systems for keeping poultry; intensive, semi-intensive and extensive (scavenging or free-range system) $[14,15]$. Whereas four systems for poultry housing in the tropics were noticed, traditional, free-range, restricted-range and intensive system [16].Reference [17] exhibited that, Intensive system for keeping poultry represents less than $30 \%$ of the total poultry population in Africa. This system existed near markets for eggs and chicken meat in urban regions. The other system is semi-intensive system which is sometimes known as backyard production system [14]. The last one is the extensive system which is known as scavenging or free-range system. It is referred to as scavenging because scavenging is the main system of feeding [17]. This system represents more than $60 \%$ of the total national poultry population in Africa [15]. Production of free-range local chickens plays important role for rural communities in Africa because it considered as one of the most important agricultural activities that supply people with rare animal protein and improve income of smallholder farmers [18]. Reference [19] found in developing countries, approximately all rural and peri-urban families have a small flock of chickens kept in the free-range system. In Myanmar, reference [20] recorded that about 59.6 million chickens which represents $84 \%$ of total chicken population were conserved in free-range system. In Bangladesh, reference [21] also reported that chickens kept in the free-range system resemble more than $70 \%$ of chicken population in the country. Despite the spread of new technologies free-range system of poultry housing keep flourishing in the tropics [22]. In spite of this progress of free-range system in the tropics its participation to rural economies is low as a result of low level of production and poor management [23]. This mainly because most of rural communities deficient in husbandry skills and training, hence they are not qualified to improve their chicken production [18].

\section{Poultry Welfare in Developing Countries}

Reference [2] noticed that, in the developing countries particularly in Africa the concern of animal welfare appeared recently as a proposal by the OIE (World Organisation for Animal Health) Sub-Regional Representation for Southern Africa after the $2^{\text {nd }}$ Global Conference on Animal Welfare held in Cairo in (2008) and the Workshop for OIE National Animal Welfare Focal Points for Africa held in Addis Ababa in (2010). Unfortunately, in the constitutions of the SADC (Southern African Development Community) Member States, like other developing countries in Africa, there are policies on agriculture, fisheries, wild animals and environment but with little or no indication to animal welfare, except in 
Tanzania which has a perfect section of animal welfare [2]. Reference [24]showed that, Namibia became the largest exporter of beef to the European Union in Africa because it establishing standards in hygiene, veterinary care and animal welfare resulted in trusted, safe and healthy products. Authors also, declared that, both Thailand and Argentina constructed and developed standards for organic production of broilers and that led to enhancement of the export markets of these products.

\section{Difficulties Facing Progress of Animal Welfare Concern in Developing Countries}

\subsection{Economical Effect}

Reference [25]informed that, developing countries are countries with a reduced living standard, undeveloped industrial base and low Human Developed Index (HDI) ${ }^{2}$ when compared to other countries. Reduced living standard in developing countries, especially in the rural areas, means low individual income and decreased chances for education and health care. Therefore, priority of people in these countries is to increase their income to fulfill living requirements. Hence the concern of animal welfare doesn't occupy a pivotal position in their priorities. In addition, their lower income lead to practices affects animal welfare, such as lack of food for these families resulted in improper nutrition of their birds. Furthermore, these birds are either badly treated or remain untreated to avoid spending money. In the big cities, birds offered more care than those in the rural area due to the presence of big companies that possess large farms of poultry and them aware about higher productivity which lead, to some extent, to good welfare, but welfare standards in these farms are still very low. This attributed to that, higher welfare standards increase the cost of the product and if the producers allowed without any support from the government or organizations they will raise the price of the product the thing that will not accepted by consumers.

\subsection{Absence of Support of Government or Organizations}

In some developing countries such as Argentina and Thailand animal welfare and organic production are encouraged by government [24]. Also some other developing countries started to establish animal welfare standards as the result of government or organizations support like Namibia, Botswana, South Africa and Zimbabwe. Consumers in these countries are be aware about the ways in which meat is produced [26]. These ensure that

${ }^{2}$ Human Developed Index (HDI) is a compound statistic of life expectancy, education and income indices to rank countries into four tires of human development. It was created by economist Mahbubul Haj, followed by economist AmartyaSen in 1990, and published by the United Nations Development Programme. progress of animal welfare concern and establishment of its standards required a government or organizations support the thing that is absent in most developing countries. This support appears in different ways, for example, in Namibia government participates in composing of Meat Board of Namibia which is responsible for control of beef industry, contact between industry and customers and enhancement of industry health and welfare standards [24]. Also finance of researches regarding animal welfare is another form of government or organizations support. In addition, government should offer special services that reduce the production cost to the producers those perform animal welfare standards in their farms.

\subsection{Lack of Skills of Proper Poultry Management}

This mainly due to lower individual income and level of education, therefore they unable to read or to take courses about the proper ways of poultry management so as to progress health conditions of birds and improve their welfare.

\section{Conclusion}

As mentioned above poultry welfare in developed countries is progressing when considering establishment of welfare standards and regulations, mainly due to scientific development in addition to governments and Organizations activities. In developing countries economical factor is the major cause of inhibition of scientific development. It was concluded that, to enhance poultry welfare concern in developing countries scientific researches, particularly that considering poultry welfare, should be encouraged and financed by organizations and working groups those aware about poultry welfare. Governments of the developing countries should take their role of supporting poultry welfare concern by constructing boards or councils that control and regulate poultry welfare standards. In addition, to supply producers with services to reduce cost of the product. Furthermore, skills of small-holders should be improved by offering courses regarding proper poultry management. Finally governments in coordination with organizations should perform semi-annual or annual workshops about poultry welfare concern in developing countries to improve the awareness.

\section{References}

[1] Elson HA, de Jong IC, Kjaer JB, Sossidou EN, Tauson R. Poultry welfare management: WPSA Working Group Nine. World`s Poult Sci J. 2012; 68: 768-775.

[2] World Organization for Animal Health, Sub-Regional Representation for Southern Africa. Animal welfare in OIE member countries and territories in the SADC region: Summaries of baseline country assessments. OIE, Paris, France. 2011; 1-3. 
[3] Dawkins MS. From an animal's point of view: Motivation, fitness and animal welfare. Behav Brain Sci. 1990; 13: 1-9 (Abstract).

[4] EFSA. The welfare aspects of various systems of keeping laying hens. EFSA Journal. 2005; 197: 1-23.

[5] Moura DJ, Nääs IA, Pereira DF, Silva RBTR, Camargo GA. Animal welfare concepts and strategy for poultry production: a review. Braz J Poult Sci. 2006; 8: 137-147.

[6] FAWC. Farm animal welfare: Health and disease. FAWC, London, UK. 2012. http://www.defra.gov.uk/fawc/.

[7] Blokhuis HJ. Intensive production units and welfare: domestic fowl Rev Sci Tech off Int Epiz. 1994; 13: 67-78.

[8] Penda PC. Egg and poultry technology house. Publishing House PYT Ltd. Janipura India. 1985; 2-4.

[9] Akinyosoye VO. Poultry production in senior tropical agriculture. Macmillan Publisher Limited London Reprint. $1985 ; 161-165$.

[10] Rodić V, Perić L, Pavlovski Z, Milošević N. Competitiveness of table eggs from non-cage housing systems. Biotech Anim Husb. 2010; 26: 117-128.

[11] Blokhuis HJ, Van Niekerk TF, Bessei W, Elson A, Guémené D, Kjaer JB, Maria Levrino GA, Nicol CJ, Tauson R, Weeks CA, Van de Weerd HA. The Lay Wel Project: welfare implications of changes in production systems for laying hens. World`s Poult Sci J. 2007; 63: 101-114.

[12] Harrison R. Animal Machines. London: Vincent Stuart. 1964

[13] Jones RB. Role of comparative psychology in the development of effective environmental enrichment strategies to improve poultry welfare. Inter J Comp Psychol. 2002; 15: 77-106.

[14] Sonaiya EB. The context and prospects for development of smallholder rural poultry production in Africa. In: CTA Seminar Proceedings, vol. 1, Smallholder Rural Poultry Production Seminar, Thessaloniki, Greece. 1990; 35-52.

[15] Kitalyi AJ. Village-chicken production systems in rural Africa: Household food security and gender focus. FAO, Animal Health and Production Series Rome, Italy. 1998; Paper No. 142
[16] Adegbola TA, Anugwa OI, Nwosun CC, Okorie AU, Orji BI. Animal science. In: Youdeowei A., Ezedinma F. O. C. and Onazi O. C. (eds). Introduction to Tropical Agriculture. Longman, London. 1986; 198-239.

[17] Kitalyi A J. Family poultry management systems in Africa: The scope and effect of family poultry research and development. INFPD/FAO E-conference.1999; http://www.fao.org/ag/againfo/themes/en/infpd/documents/e conf_scope/paper3.html

[18] Mlozi MRS, Kalengi AVM, Minga UM, Mtambo AM, Olsen JE. Marketing of free-range local chickens in Morogoro and Kilosa urban markets, Tanzania. Livest Res Rural Dev. 2003; Vol. 15, Article $2 \mathrm{http}: / / w w w .1 \mathrm{rrd} . o r g / / \mathrm{rrd} 15 / 2 / \mathrm{mloz} 152 . \mathrm{htm}$.

[19] Jens Christian R, Anders B, Charlotte V, Ainsh MC, Lone F. Keeping village poultry. A technical manual for small-scale poultry production. Copenhagen, Denmark. 2004

[20] Henning J, Pym R, Hla T, Kyaw N, Meers J. Village chicken production in Myanmar-purpose, magnitude and major constraints. World`s Poult Sci J. 2007; 63: 308-322.

[21] Huque QME, Paul DC. Strategies for family poultry production with special reference to women participation. In: 1st SAARC Poultry Conference, 24-26 September, Pune, India. 2001; www.cipav.org.co/Irrd/Irrd9/3/bang931.htm.

[22] Ovwigho BO, Bratte L, Isikwenu JO. Chicken management systems and egg production in Delta State Nigeria. Inter J Poult Sci. 2009; 8: 21-24.

[23] Shumba EM, Whingwiri EE. Prospects for increased livestock production in communal areas: An agronomist perspective. In: Research and Extension for Livestock in Communal Area Farming Systems10-18 February. Henderson Research Station, Mazoe, Zimbabwe.1988.

[24] Bowles D, Paskin R, Gutiérrez M, Kasterine A. Animal welfare and developing countries: Opportunities for trade in high-welfare products from developing countries. Rev Sci Tech Off Int Epiz. 2005; 24: 783-790.

[25] Sullivan AO, Sheffrin SM. Economics: Principles in Action. Pearson Prentice Hall, New Jersey. 2003; 471.

[26] Paskin RD. Good agricultural practices: what does the future hold? In proceedings: FAO/ Meat Board of Namibia/ NASSP Workshop on good agricultural practices for the livestock sector. 6-8 April, Windhoek. Namibia. 2004. 